\title{
A ESCOLA NORMAL DO PARÁ E O IDEAL DE PROFESSOR ILUSTRADO E APLICADO (1838 - 1871)
}

Rogério Guimarães Malheiros ${ }^{1}$

João Ribeiro dos Santos Filho ${ }^{2}$

\section{RESUMO}

Propomos neste artigo um debate acerca dos ideais de Instrução Pública dos Presidentes da Província do Grão-Pará, que, em meio às mudanças econômicas e sociais, elegeram a Escola Normal como modelo de formação de professores que poderia sanar os problemas do sistema de Instrução Pública da Província. Procuramos observar também os embates na imprensa paraense, da época, relativos à Lei 669, de 13 de abril de 1871, que cria a Escola Normal do Pará, como forma de compreendermos os meandros discursivos das tendências liberal e conservadora relacionados a esta medida legal, bem como a disputa, travada por esses grupos, dos projetos políticos de sociedade e de educação para o Império do Brasil e para a Província do Grão-Pará.

Palavras-Chave: Escola Normal do Pará; Formação de Professores; Instrução Pública.

\section{NORMAL SCHOOL OF PARA TEACHER AND THE IDEAL OF APPLIED AND ILLUSTRATED (1838 - 1871)}

\section{ABSTRACT}

We propose in this article a debate about the ideals of Presidents of Public Instruction of the Province of Grão-Pará, which, amid the economic and social changes, elected the Normal School as a model of teacher education that could solve the problems of the system of Public Instruction the Province. Also tried to observe the clashes in the press Pará, at the time, relating to Law 669 of 13 April 1871 establishing the Normal School of Pará, in order to understand the intricacies discourse of liberal and conservative trends related to this legal action, and the dispute waged by these groups, the political projects of society and education for the Empire of Brazil and for the Province of Grão-Pará.

Keywords: Pará Normal School; Teacher Training; Public Instruction.

\section{Introdução}

Neste artigo, desenvolvemos uma análise acerca dos ideais de instrução pública dos Presidentes da Província do Grão-Pará, no período de 1838 a 1871. Neste período, marcado por mudanças econômicas e sociais, como adiante veremos, a classe dirigente da Província do Grão-Pará elegeu a Escola Normal como um modelo de formação de professores.

Propomos, desta forma, uma discussão acerca destes ideais de instrução pública, a partir da utilização de fontes históricas do período (relatórios, discursos) e com base em autores que escreveram sobre este contexto histórico.

No texto, iremos manter nas citações diretas a forma de grafia das palavras com a norma gramatical vigente no período histórico sob estudo. 


\section{A implantação da Escola Normal como modelo de instrução pública}

De acordo com as bases da lei, [...], o distincto administrador instituiu e organisou uma escóla normal, destinada á formar n'um curso de 3 annos, professores habeis a instruir e habilitar os actuaes, que ainda não estão preparados para bem desempenharem o magisterio; [...] (PARÁ, 1871, p. 9).

Conforme a epígrafe em destaque, extraída do Relatório do Presidente da Província do Grão-Pará, Abel Graça, datado de 15 de agosto de 1871, a criação da Escola Normal do Pará iria servir para formar professores e habilitar os que já atuavam no sistema de Instrução Pública da Província. No entanto, em conformidade com este objetivo está o projeto da classe abastada da Província e de seus dirigentes administrativos, que pretendiam, para além do processo de habilitar os professores, formar agentes disseminadores dos ideais modernos de ordem, progresso e civilização.

Neste sentido, um mês após a publicação da Lei 669, de 13 de abril de 1871, que cria a Escola Normal do Pará, ocorreu a instalação desta instituição, e, em junho do mesmo ano, iniciaram-se as aulas, que, naquele momento, passariam a ser ministradas nas dependências do Liceu Paraense e do Colégio Nossa Senhora do Amparo. ${ }^{3}$

Fato este que, para o Presidente Abel Graça, significou grande progresso do sistema de Instrução Pública, haja vista que a Província não padeceria mais pela falta de preparo e vocação dos professores que há muito havia sido identificada, por seus antecessores, como sendo a grande causa de não se obter os avanços desejados para a instrução pública da Província, afirmando que "[...] com a criação da escóla normal [...] a provincia do Pará póde em pouco tempo ver emfim realisados os seus votos e o triunpho de seus esforços em pról da instrucção de seus filhos (PARÁ, 1871, p. 13).

Havia na Província do Pará, por ocasião da instalação da Escola Normal, um ambiente político, econômico e social propício para esta ação promovida pelo Governo da Província. Desde os anos finais da década de 1840, a alfândega de Belém vinha obtendo, ano após ano, elevadas arrecadações financeiras por suas exportações, fato que havia sido atribuído à crescente comercialização da borracha. Somada a esta questão, está a introdução da navegação a vapor na Província, pois com a utilização de embarcações a vapor passou a ser possível o transporte de grande quantidade de mercadorias para o porto de Belém, dentre elas, a goma elástica. Cabe ressaltarmos que estas embarcações, além da quantidade de mercadorias que transportavam, também efetuavam o transporte em curto espaço de tempo. Com o aumento da capacidade de transporte de mercadorias tivemos, por conseguinte, uma elevação da arrecadação alfandegária, possibilitando meios financeiros para por em prática o projeto de modernização da cidade de Belém, capital da Província do Grão-Pará (Cf. MALHEIROS, 2012).

Seguindo esta linha de raciocínio, podemos perceber que o melhoramento e a expansão da Instrução Pública estiveram em consonância com o projeto de modernização pensado pela classe abastada da Província, que exigia, por ocasião de seu enriquecimento, devido ao comércio gomífero, grandes reformas urbanas e sociais, no sentido de alinhar a cidade de Belém aos costumes e aos hábitos civilizados, à luz do exemplo de organização urbana e social de Paris.

Deste modo, seria necessário alinhar a Província do Pará ao que se entendia enquanto moderno e civilizado, todavia, seria oportuno não apenas as reformas urbanísticas, mas também modelar os cidadãos paraenses aos hábitos considerados 
civilizados, missão esta conferida ao sistema de Instrução Pública da Província, o que está diretamente ligado à premente necessidade de se formar professores comprometidos com este modelo de instrução.

A partir de obras de autores como Villela (1992), Monarcha (1999) e Araújo (2008), podemos depreender que os ideais de progresso e civilização foram a tônica discursiva que justificava a necessidade de se instituir uma Escola Normal para se formar e habilitar professores. Estes autores ratificam ainda, que houve, tanto no caso da Província do Rio de Janeiro, quanto no caso de outras Províncias do Império, a exemplo de São Paulo, uma ambiência política, econômica e social que propiciou a instalação da Escola Normal, o que também podemos perceber no caso específico da Província do Grão-Pará, muito em função do que ressaltamos acima, devido à expansão da economia gomífera, à introdução da navegação a vapor na Amazônia e à abertura à navegação internacional do Rio Amazonas.

Cumpre destacarmos ainda que a obra "As Escola Normais no Brasil: do Império à República", organizada por Araújo, Freitas e Lopes (2008), apresenta-nos uma interessante coletânea de artigos, que ratificam o que constatamos na Província do GrãoPará. Esta obra, apesar de não abranger estudos sobre a Região Norte no processo de criação e consolidação das Escolas Normais no Brasil, nos garante ricas experiências da gênese e do percurso histórico desse tipo de instituição em diversas Províncias do Império, possibilitando-nos um olhar mais aguçado sobre as especificidades e permanências do caso paraense.

Nessas experiências apresentadas na mencionada obra, percebemos as nuances do processo histórico-educacional de criação e consolidação das Escolas Normais ao longo do século XIX e início do XX, e percebemos que nas distintas experiências, os anseios políticos e sociais por reformas urbanas, com ênfase aos preceitos modernos de ordem, civilização e progresso, permearam as concepções políticas e sociais em favor da implementação de medidas relacionadas à melhoria dos respectivos sistemas de Instrução Pública, por meio da promoção de formação docente. A Escola Normal desponta, neste contexto, como modelo de instituição para melhor atender a esses anseios.

Torna-se interessante destacarmos também que os distintos projetos de criação das Escolas Normais, presentes na obra organizada por Araújo, Freitas e Lopes (2008), demonstram que esta instituição esteve também centrada na perspectiva social de criação de novos hábitos sociais de consumo, de mobilidade social e de, fundamentalmente, constituição de mecanismos que viabilizassem a proliferação entre os cidadãos de valores específicos das sociedades urbanas e industriais, o que estava em consonância com os preceitos modernos da segunda metade do século XIX. ${ }^{4}$

A opção pelo modelo normalista, nas Províncias do Brasil, ocorrera muito em função da supremacia do modelo social europeu, em especial o parisiense, entre a elite dirigente do Império e das Províncias em destaque, pois a Europa, neste momento, apresentava-se aos dirigentes imperiais e provinciais brasileiros como uma referência em matéria de modernidade. Todavia, não queremos aqui afirmar que apenas o modelo europeu esteve presente no imaginário dos dirigentes brasileiros, mas que este acabou por se sobressair entre os demais, o que se justifica pela própria tradição oriunda do período colonial. $^{5}$

A Lei 669, de 13 de abril de 1871, representou o prenúncio legalista que atenderia a esta premente necessidade de formação de professores na Província do Pará, haja vista que sua promulgação fora em função dos discursos proferidos por sucessivos Presidentes da Província que figuravam o modelo normalista como o essencial para atender às prementes necessidades de preparo dos professores do Grão-Pará, o que não nos parece 
estranho, pois este modelo de formação de professores, assim como o projeto de modernização de Belém, também fora oriundo da França, que se apresentava a grande parte dos administradores da Província, como sendo a principal referência em termos de modernidade e civilização. ${ }^{6}$

Cumpre ressaltarmos, que para além desta premissa de modernidade e de civilização do povo, o sistema de Instrução do Pará, assim como seus professores, teria que esta habilitado a formar uma consciência industrial entre os cidadãos da Província, haja vista que, tanto o Presidente Couto de Magalhães quanto o Secretário Geral da Província, Ferreira Penna, identificavam que estes não possuíam, naquele momento, uma premente necessidade de promover a industrialização da Província, muito em função dos recursos naturais disponíveis para sua subsistência, o que os proporcionava uma relação social específica com a natureza, levando-os a relegar à segundo plano a criação de indústrias no interior do Pará (Cf. PARÁ, 1864, p. 7).

Ainda acerca do Relatório de 1871, apresentado pelo Presidente Abel Graça, destacamos que este Presidente considerava que

[...] nenhum paiz alcançará jamais uma prosperidade real sem tomar por guia o desenvolvimento da intelligencia. A instrucção publica, que eu tomo como synonimo de instrucção popular, é tão necessaria á um povo, como a luz que nos faz distinguir uns dos outros: é o pharol que illumina o espirito dos cidadãos e ensina-lhes á serem bons paes, bons amigos e bons patriotas.

Se a necessidade da instrucção é tão imperiosa, o primeiro dever dos que têm á seu cargo promover o bem geral é procurar satisfazel-a (Id., 1871, p. 13).

Depreendemos, neste sentido, um avizinhar aos ideais modernos de Instrução, pois Abel Graça ressalta quanto à necessidade de se propagar as luzes por meio da instrução do povo, sendo um dever dos Governos promovê-la e satisfazê-la de acordo com as necessidades demandadas pela sociedade.

Podemos inferir que se trata da influência do pensamento francês, do final do século XVIII, em especial o pensamento do filósofo Marquês de Condorcet, que por meio de seus ensaios sur l'instruction publique e seu Rapport de 1792, já publicizava seus ideais de Instrução Pública pautada como dever do Estado e como mecanismo de ilustração (no sentido de tornar ilustres) dos cidadãos franceses à luz da razão, da moral e do cientificismo (Cf. MALHEIROS, 2012; SILVA, 2010; BOTO, 2003; COUTEL, C., 1996; KINTZLER, K. C., 1994).

Ao reconhecermos questões referentes à influência de ideias e de modelos de instrução oriundos do continente europeu e dos Estados Unidos da América, depreendemos que a partir de 1867, após a abertura à navegação internacional do Rio Amazonas, tivemos um aumento significativo de circulação de pessoas, ideias e modelos de instrução que passaram a influenciar os enunciados dos administradores e dirigentes da Instrução Pública do Grão-Pará. Influências estas que não depositamos apenas à abertura do Rio Amazonas à navegação internacional, mas também ao fato de alguns Presidentes da Província terem subsidiado a formação de alguns professores no continente europeu, mais precisamente na França, e à antiga relação estabelecida com aquele continente oriunda ainda de tempos coloniais.

Quanto à influência do modelo estadunidense, percebemos que fora em função dos ideais republicanos que estavam bem evidentes no Império do Brasil já no início da segunda metade do século XIX, que foi se acentuando paulatinamente até o final do século, 
quando, em 15 de novembro de 1889, os políticos do Império aderem oficialmente o republicanismo no Brasil por meio da proclamação da República dos Estados Unidos do Brasil, e aclamada no Pará um dia posterior, pela comissão republicana composta pelos comandantes do Exército e da Armada e pelos civis do Club Republicano do Pará. $^{7}$

Cumpre evidenciarmos que a própria abertura à navegação internacional do Rio Amazonas ocorreu devido a pressões internacionais, em especial dos Estados Unidos, que tentavam influenciar o governo brasileiro, desde a primeira metade do século, pela autorização às suas embarcações, de explorarem o interior da Amazônia, fato que só fora normatizado a partir de 1867, por meio do Decreto 3.920, de 31 de julho (Cf. GREGÓRIO, 2008).

No tocante a essas especificidades políticas, econômicas e culturais, observamos o afloramento discursivo em prol da instalação de uma Escola Normal destinada a formar e habilitar os professores do Grão-Pará. Formação esta que deveria estar intimamente ligada ao projeto, da classe abastada e dos dirigentes da Província, em alinhar a sociedade paraense aos hábitos culturais parisienses. No entanto, percebemos que este projeto de modernização da cidade e de seus habitantes acabou por acotovelar-se nas especificidades amazônicas, haja vista que no interior da Província, não havia, naquele momento, uma premente necessidade de industrialização, o que evidenciamos anteriormente por meio do Relatório de Couto de Magalhães e Ferreira Penna, apresentado no ano de 1864, que demonstrara a relação social que os habitantes da zona do Tocantins mantinham com a natureza.

Além desta relação social com a natureza, havia ainda o problema da extensão do território da Província e da dispersão populacional neste território, que acabavam por dificultar o acesso e, por conseguinte, a promoção dos mecanismos de instrução dos cidadãos, que muitas vezes habitavam porções bem afastadas de qualquer núcleo populacional, o que os levavam a permanecer fadados ao analfabetismo.

O projeto de formação de professores pelo modelo normalista também fora pautado como um dos mecanismos para proporcionar uma Instrução Pública que pudesse desenvolver uma mentalidade industrial, que estivesse intimamente ligada aos ideais modernos de ordem, civilização e progresso, e de disseminação do ensino primário no interior da Província, funcionando como o elemento propagador destes ideais e permeado pelas premissas modernas de instrução, isto é, de moral, razão e cientificidade.

$\mathrm{O}$ projeto de modernização da cidade de Belém e o projeto de promoção e eficiência do sistema de Instrução Pública coadunavam no objetivo de disseminação dos ideais modernos de civilização e progresso na Capital e no interior da Província. São projetos oriundos de um contexto sociopolítico ainda da primeira metade do século XIX e que denotam a íntima relação entre a modernização que se queria e a instrução que a possibilitaria.

Os dirigentes da Província, em sua maioria, acreditavam que o sistema de Instrução Pública do Pará só poderia obter relevantes resultado mediante a institucionalização de uma Escola Normal que possuísse a finalidade específica de formar e capacitar os professores do Grão-Pará à luz dos pressupostos modernos de instrução.

O sistema de Instrução da Província, nesse sentido, foi considerado como o meio de moldar os cidadãos paraenses para o vir a ser da Província, isto é, formar cidadãos civilizados, que passariam a fazer parte de um contexto social de modernidade, progresso e civilização, e a Escola Normal seria a instituição que melhor atenderia a esse objetivo.

Entre os presidentes que ratificaram esta necessidade de criação de uma Escola Normal destinada a formar e a habilitar os professores do Grão-Pará destacamos Soares D’Andréa, que esteve a frente do Governo da Província no Período de 1836 a 1839; 
Bernardo de Souza Franco, nos períodos de 1839 a 1840 e 1841 a 1842; João Antonio de Miranda, de fevereiro a novembro de 1840; Fausto d'Aguiar, que permaneceu à frente da Província no período de setembro de 1850 a agosto de 1852; Francisco Brusque, de junho de 1861 a janeiro de 1864; Lacerda Chermont (Barão d'Arary), que dirigiu a Província por vários períodos, dentre os quais, de 28 de junho a 27 de outubro de 1866, de 9 de abril a 1 de junho de 1867 e de 6 de agosto a 29 de setembro de 1868; Joaquim Raimundo Lamare, que exerceu a função no período de junho de 1867 a agosto de 1868; Abel Graça, de abril a setembro de 1870 e de julho de 1871 a junho de 1872; e por último, o Presidente Joaquim Pires Machado Portella, em seu curto mandato, que durou de janeiro a abril de 1871, quando fora de direito criada a Escola Normal do Pará e de fato instalada durante o mandato do Presidente Abel Graça.

No caso específico da Província do Grão-Pará, tivemos ainda na primeira metade do século, para sermos mais precisos, no ano de 1839, a primeira iniciativa de institucionalização de uma Escola Normal destinada ao preparo de professores primários, por meio da Lei 33, de 30 de setembro.

Segundo a mencionada Lei, o Governo da Província estaria autorizado a instituir uma Escola Normal na cidade de Belém, capital da Província, e de enviar um paraense para capacitar-se em igual instituição criada na Província do Rio de Janeiro ou contratar pessoa ali formada para dirigir a Escola Normal do Pará que se pretendia criar (Cf. PARÁ, Lei 33, de 30 de setembro de 1839).

No entanto, somente a partir de 1841, por meio da Lei 97, de 5 de julho, é que se criou uma "aula de ensino normal" na capital da Província (Cf. PARÁ, 1854, p. 43). Com a criação do Liceu Paraense, no art. 13 da citada Lei, determinou-se que uma sala de aula dessa instituição deveria abrigar o "ensino normal" da Província.

Para o historiador Brito (2005), apesar da iniciativa governamental em se criar um "curso normal" na capital da Província, o mesmo acabou por padecer no esquecimento administrativo do Liceu Paraense e do Governo da Província, haja vista que as mudanças de governadores eram constantes, não havendo uma continuidade de projetos, uma vez que as concepções educacionais eram distintas. ${ }^{8}$

Desta maneira, destituído de qualquer forma organizacional, como regimento e de Lei normatizadora específica, o "curso normal" do Grão-Pará acabou por cair no esquecimento administrativo nesta última década do primeiro quartel do século XIX, mas que ganha notoriedade nos discursos de sucessivos Presidentes da Província durante a segunda metade do século XIX.

Como podemos notar, os discursos tecidos em favor da criação de uma Escola Normal na Província do Pará datam ainda da primeira metade do século XIX e, já a partir de 1850 fora intensificado e passou a ser objeto de discussão nos Relatórios dos Presidentes elencados acima, que, em sua maioria, defendiam esta instituição como a que melhor atenderia as necessidades de formação e habilitação dos professores do sistema de Instrução Pública do Grão-Pará.

Porém, em contraponto aos enunciados proferidos em favor da criação da Escola Normal na capital da Província do Pará, tivemos no Relatório do Presidente Leitão da Cunha, apresentado à Assembleia Legislativa Provincial no ano de 1858, um discurso contrário a estas aspirações pelo modelo normalista de formação de professores, haja vista que este Presidente, baseado em suas leituras acerca do tema, não concebia que esta instituição fosse capaz de sanar os problemas que a Província vinha enfrentando em seu sistema de Instrução Pública.

Para Leitão da Cunha, estas Escolas Normais "[...] que tendo tido origem e florescido na Europa, degenerarão completamente quando, transportadas para nosso paiz, 
[...]” (PARÁ, 1858b, pp. 12-13). Também para Leitão da Cunha, as experiências da Província do Rio de Janeiro, Bahia, Minas Gerais e São Paulo, teriam sido a prova de que o modelo de instituição da Escola Normal não poderia sanar os problemas que haviam no sistema de Instrução Pública do Pará, em especial o problema da falta de preparo e vocação dos professores. ${ }^{{ }^{3}}$

Como podemos perceber, a criação da Escola Normal do Pará não fora uma unanimidade discursiva entre os dirigentes do Grão-Pará, mas se destacou nos discursos da maioria dos Presidentes da Província, entre os anos de 1838 a 1872, como sendo a instituição que poderia sanar os problemas do sistema de instrução pública do Grão-Pará, haja vista que, como bem pontuou o Presidente Abel Graça, em seu Relatório de 1871, a Escola Normal do Pará seria capaz de remover "[...] estas causas efficientes do atraso da instrucção [...]" (GRAÇA, 1871, p. 8).

\section{A Lei 669, de 13 de abril de 1871, e sua repercussão na imprensa paraense}

Após a publicação da Lei 669 de 1871, pelo então Presidente da Província do GrãoPará, Joaquim Pires Machado Portella, os periódicos de Belém "O Liberal do Pará" e "O Diário de Belém", representantes dos Liberais e Conservadores, respectivamente, logo se manifestaram com leituras divergentes da mencionada Lei que instituía naquele ano, 1871, a Escola Normal do Pará.

No tocante às questões relacionadas a criação da Escola Normal do Pará, ambos os periódicos divergiam, uma vez que para os conservadores a formação de professores pelo modelo normalista traria bons resultados e melhorias para o sistema de Instrução Pública da Província; enquanto que para os liberais, a Escola Normal não passava de uma medida paliativa e que não poderia resolver os problema do atraso do ensino na Província, pois a falta de uma infraestrutura nas mais variadas Vilas, Cidades e demais localidades da Província, deixaria os professores formados, por essa instituição, sem as condições necessárias para o desenvolvimento profícuo de suas atividades.

Um mês antes da publicação da Lei 669 de 1871, o Jornal "Diário de Belém" estampou em sua primeira página um artigo, onde procurou observar, segundo a concepção do articulista, a importância da formação do "mestre" para a disseminação de uma instrução pautada na moral e no desenvolvimento da "intelegencia infantil".

É uma verdade incontestável que os defeitos mais notáveis da instrucção primária são devidos á pouca capacidade que em geral tem o corpo doutrinante.

Quem faz o bom discípulo é o mestre, e desde que este não tem as habilitações necessárias para bem guiar a intelligencia infantil que começa a desenvolver-se, desde que não tenha moralidade e sentimentos religiosos para incutir no coração ainda verde o amor aos bons costumes e práticas de moral civil e religiosa a instrucção deixa de dar bons fructos, porque a verdadeira educação é aquella que prepara a inteligência e o coração para a prática do bem.

[...] preparar bons mestres é preparar bons discípulos porque estes recebem d'aquelles as primeiras práticas de estudo, os primeiros gosos da intelligencia, que se desenvolvem a proporção que o mestre faz conhecer as vantagens que delles se colhe.

[...] O primeiro mestre é, pois, um dos primeiros guias do homem no caminho de sua vida (DIÁRIO DE BELÉM, 15 de março de 1871, pp. 12 apud BRITO, 2005, p. 30). 
Logo, na visão do periódico Conservador de Belém, há uma premente necessidade de desenvolver na Província, mecanismos para a formação de professores que pudessem propagar o ensino primário baseado nos "bons costumes", na "moral civil e religiosa", bem como em conhecimentos pautados no desenvolvimento da "intelligencia" da criança, o que marcaria o tom discursivo do Presidente Jaquim Pires Machado Portella no ato da aprovação da Lei 669, de 13 de abril de 1871.

Trata-se também de uma maneira de anunciar e justificar a necessidade da criação de uma instituição destinada ao preparo específico de professores na Província, uma vez que, conforme epígrafe acima, o articulista do Jornal foi enfático em afirmar que [...] preparar bons mestres é preparar bons discípulos porque estes recebem d'aquelles as primeiras práticas de estudo, os primeiros gosos da intelligencia, [...]" (Idem).

Brito (2005) destacou, em seu trabalho, que as verdadeiras intenções do governo da Província fora o de manter sua estrutura administrativa intocável, daí a necessidade de se voltar para o espaço escolar, por meio de proposições e medidas que pudessem expandir sua ideologia e controlar, principalmente, os professores, o que o leva a concluir que a formação pensada para os professores, à luz do modelo normalista, possuía a finalidade de transmitir um conhecimento que refletisse os ideais da ordem vigente.

Acreditamos que a reforma da instrucção primária é a mais grandiosa empresa da civilização moderna, [...] a reforma deve começar pela base, isto é, pelo mestre que sem educação moral, intellectual e religioso não pode ser bom.

Uma escola normal ou um curso em que os aspirantes ao magistério se eduquem pela cabeça e pelo coração, e onde aprendam um methodo de ensino compatível com a intelligencia dos meninos é uma necessidade de que não deve ser addiada por aquelles que trabalham em favor da instrucção primária (Idem).

Depreendemos, por essa forma, que o periódico conservador "Diário de Belém" se tornou o porta voz governamental, de forma que o mesmo justificava a necessidade de criação de uma Escola Normal para a formação de professores, bem como a reforma da instrução primária como mecanismos de desenvolvimento dos preceitos modernos de ordenamento, civilização e progresso, que acabavam por permear os enunciados e os debates dos dirigentes e políticos nacionais e dos Presidentes do Grão-Pará.

Por conseguinte, a inserção do Grão-Pará no mundo reconhecidamente moderno e civilizado perpassaria pela reorganização do sistema de Instrução Pública da Província e pela implementação de medidas de formação de professores, onde a Escola Normal desponta como modelo para alguns setores da sociedade, que exigem uma melhor qualificação dos professores como forma de se obter um profícuo resultado do sistema de Instrução Pública da Província, de forma que estes seriam a base da constituição de uma sociedade pautada na ordem econômica e social vigente.

$\mathrm{O}$ articulista do "Diário de Belém", por meio do artigo que debatemos até agora, enfatizou também que,

[...] transmittir as novas gerações o espírito nacional, as ideas Moraes e religiosas, que constituem a vida tradicional do povo; propagar os conhecimentos úteis para as classes inferiores da sociedade [...] Formar homens e cidadões offerecendo na educação da infância uma base segura a prosperidade publica e ao progresso da civilisação (Idem). 
Como podemos notar, o Jornal "Diário de Belém" fora enfático, um mês antes da aprovação da Lei 669, de 13 de abril de 1871, em defender a relevância de se formar professores para o desenvolvimento dos preceitos modernos de ordenamento, civilização e progresso. Nesta parte final do artigo, depreendemos também que a defesa de uma educação pautada numa moral e na própria religiosidade do povo, denota a ambiência constitucional do Estado brasileiro, pois este era adepto do catolicismo romano, por meio do sistema do padroado, ${ }^{10}$ havendo uma estreita relação da Instrução Pública com a Igreja Católica, haja vista que muitos Presidentes da Província consideravam os párocos os melhores mestres que haviam na região.

Todavia, contrapondo-se ao "Diário de Belém", por conseguinte, aos políticos conservadores, o Jornal "O Liberal do Pará", diversas vezes contesta as ações provenientes do Governo da Província. Nesse sentido, em maio de 1871, portanto, quase um mês após a criação da Escola Normal do Pará, o periódico de tendência liberal, em tons provocativos, contesta a eficiência da aplicabilidade das mudanças, legalmente autorizadas na área do ensino, pelo então Presidente Joaquim Pires Machado Portella, onde o articulista do referido periódico destaca que,

Até que finalmente, depois de oito dias de silêncio apresentou-se o Diário de Belém, defendendo-se do Novíssimo regulamento da instrucção pública.

[...] O Novíssimo regulamento de instrucção pública é obra de momento, cheio de imperfeições e acovas, capaz de prestar-se a todos os sophismos com que se poderá inutilizar suas melhores disposições, carregado de espantoso pessoal administrativo que só serviria para perpetuar a morosidade dos actos da administração, e para a perseguição dos professores desaffeiçoados.

Provocamos o Diário de Belém a que nos declare, sem rodeios, francamente, como acabamos de fazer, e em nome do partido a quem diz pertencer:

$1^{\circ} \mathrm{Si}$ quer a instrucção espalhada pelo povo com liberdade e sem peãs [prisões]

$2^{\circ} \mathrm{Si}$ aceita a fundação de escholas primarias noturnas, onde o povo vá beber a necessária instrucção, que os torne aptos á conhecer seus direitos civis e políticos.

[...] $4^{\circ} \mathrm{Si}$ dese a criação da escola normal, onde se preparem professores que, cônscios de sua dignidade, se não curvem a importância menos decorosas.

Entretanto acompanhemos por agora a redação do Diário.

Diz ella que só uma opposição mesquinha seria capaz de negar ao sr. Portella a justa gratidão que lhe devemos.

Si o povo paraense deve gratidão ao Sr. Portella, que destruiu a obra monumental do sr. Siqueira, é natural que deva execração a este ultimo acto reprovado que praticou, acto que forçou seu correligionário a pôr o sello official da desmoralização (O LIBERAL DO PARÁ, O Regulamento da instrucção pública, 5 de maio de 1871 , p. 1 apud. BRITO, 2005, p. 32).

Como podemos perceber, as prerrogativas relacionadas ao novo regulamento da Instrução Pública e a criação da Escola Normal do Pará, provocam um clima de tensão entre as classes políticas da Província. Segundo o periódico dos liberais, as ações e medidas relativas a Instrução Pública promovidas, nos últimos meses, pela presidência da Província, à época dirigida por Joaquim Pires Machado Portella, além de tentarem 
mascarar a morosidade e falta de eficiência do poder público neste ramo, acaba por tentar coagir os professores que não eram adeptos do conservadorismo governamental.

Conforme epígrafe acima, depreendemos que havia forte disputa entre os jornais "Diário de Belém", de tendência conservadora, que defendia as medidas da Presidência da Província relacionadas ao sistema de Instrução Pública, e "O Liberal do Pará", de tendência liberal, que questionava a eficiência e as verdadeiras intenções do poder público para com as medidas de reorganização do sistema de Instrução Pública e a criação da Escola Normal do Pará.

O periódico dos liberais evidenciava também a necessidade de se implantar o ensino noturno nas escolas da Província como forma de garantir ao povo o direito à instrução e a conhecer seus direitos civis e políticos, além do princípio de liberdade de ensino, o que nos leva a concatenarmos ao que fora defendido pelos franceses no final do século XVIII e ao que Ferreira Penna havia debatido em seu artigo publicado no jornal "Colombo" no ano de 1869. Vale ressaltarmos que Ferreira Penna também era adepto da tendência liberal, apesar de compor por vários anos o Governo da Província como Secretário Geral de Governo (Cf. MALHEIROS, 2012; MALHEIROS \& ROCHA, 2012).

Em meio a essas controversas políticas e ideológicas é que foi criada a Escola Normal do Pará, onde os conservadores exaltavam tal medida, enquanto que os liberais a ponderavam e teciam pontuais críticas. No entanto, como explicita Brito (2005), em meio às vaidades pessoais dos Presidentes da Província, estes acabavam por entrelaçar as questões políticopartidárias e os projetos governamentais que porventura viessem a beneficiar o sistema de instrução do Grão-Pará. Como exemplo emblemático, temos no ano de 1872 a extinção da Escola Normal do Pará por meio da Lei 757, de 19 de dezembro do mesmo ano, sancionada pelo Vice Presidente da Província, Barão de Santarém, onde determinou que,

Art. $1^{\circ}$. Fica extincta a escola normal, sendo o respectivo curso anexado ao Lycêu Paraense.

$[\ldots]$.

Art. $6^{\circ}$ As alumnas da referida escola, que já começaram o curso continuarão a ser leccionadas no collegio de N. S. do Amparo pelos professores do ensino respectivo, até que as mesmas o tenham concluído. $[\ldots]$.

Art. $7^{\circ}$. Fica em pleno vigor para os alumnos do Lycêu Paraense, que concluírem o curso normal, as mesmas vantagens e garantias concedidas pelo regulamento da escola.

[...].

Art. $11^{\circ}$ Revogam-se as disposições em contrário (PARÁ, Lei no 757, de 19 de dezembro de 1872).

Deste modo, a Escola Normal do Pará, com um pouco mais de um ano e meio de existência legal, é extinta e anexada ao Liceu Paraense. No entanto, a lei que extingue a Escola Normal resguarda o direito das alunas do curso normal do Colégio Nossa Senhora do Amparo em finalizá-lo, haja vista que, como havíamos pontuado anteriormente, os cursos da Escola Normal do Pará fora instalado, inicialmente, nas dependências do Liceu Paraense e do Colégio Nossa Senhora do Amparo (Cf. PARÁ, 1874b).

Entremente, a Escola Normal do Pará esteve, desde sua criação, em meio as disputas políticas e ideológicas entre liberais e conservadores, disputas estas que na década de 1880 resultaria na mudança de regime governamental no Brasil, ou seja, na mudança do Império para a República. Porém, a partir de 1874 a Escola Normal do Pará volta a ser 
organizada pelo Governo da Província, ${ }^{11}$ estendendo suas atividades por longos anos durante o século XX, formando professores, que em meio as disputas políticas e sociais, foram também alvos de duras críticas (Cf. BRITO, 2005).

\section{Considerações finais}

Neste artigo, optamos por observar o contexto social, político e econômico que levou o Governo da Província do Pará a instalar uma Escola Normal destinada ao preparo específico dos professores primários da Província, o que procuramos fazer privilegiando os discursos dos Presidentes da Província, no período de 1838 a 1871, de forma que pudéssemos, por meio da análise do discurso, observar os pressupostos políticos e ideológicas que marcaram a historicidade daqueles que estiveram a frente do Governo do Grão-Pará ao longo dos anos que delimitamos para nosso estudo.

Nos dedicamos também em ressaltar as controversas políticas e ideológicas, entre consevadores e liberais, por meio dos periódicos "O Liberal do Pará" e "Diário de Belém", que circulavam na capital da Província no ano da aprovação da Lei 669, de 13 de abril de 1871, que criou a Escola Normal do Pará.

Essas questões referentes as mencionadas controversas políticas e ideológicas, assim como o contexto social e econômico da Província no período, permite-nos depreender que a Escola Normal do Pará fora objeto de aspirações políticas e sociais que foram pensadas a partir de um modelo de ensino e sociedade, modelo este que já evidenciamos como sendo o parisiense, não sem controversas e resistências, pois como bem pontuamos, o modelo estadunidense também já se figurava como uma alternativa para o sistema de Instrução Pública do Pará e do Império do Brasil. Desta maneira, não nos parece estranho a opção feita pelo modelo normalista de formação de professores, haja vista que este fora oriundo da França, da segunda metade do século XVIII, que inicialmente, por ocasião de sua gênese no século XVII, esteve sob a gerência da Igreja Católica e, posteriormente, fora instituído pelo Estado francês no período thermidor, devido proposição feita por Lakanal durante a Convenção Nacional francesa de 1794 (Cf. MALHEIROS, 2012).

Após apreciação da proposição de Lakanal, a Convenção Nacional francesa adota para o Estado Francês o modelo normalista de formação de professores, proporcionando, cinco anos após a eclosão da Revolução Francesa, a fundação de uma Escola Normal, que teve um curto prazo de existência, de janeiro a maio de 1795, mas que influenciaria diversos sistemas educacionais durante o século XIX, entre eles o do Grão-Pará, onde seus dirigentes o adotaram como modelo e, por ocasião do projeto de modernização da cidade de Belém, o adaptaram para atender este objetivo, isto é, modelar a cidade e seus cidadãos à luz das premissas modernas de ordem, civilização e progresso.

\section{Quadro 1}

Escravos: Divisão por Sexo e Faixa Etária no Município de Belém, 1850-1870

Fonte: 178 Inventários post-mortem - Arquivo Público do Estado do Pará.

Total de Escravos: 2.263

Nesta parte final de nosso trabalho, procuramos também delinear os pressupostos discursivos dos Presidentes da Província do Pará que, permeados do ideal social moderno, elegeram a instrução como elemento civilizador e propagador dos ideais de ordenamento e 
progresso, pautados na constituição de uma mentalidade industrial entre os cidadãos do

\begin{tabular}{|c|c|c|c|c|c|c|c|c|c|c|c|c|}
\hline \multirow[b]{3}{*}{ ANOS } & \multicolumn{6}{|c|}{ Faixa Etária $\left(\mathbf{n}^{0}\right)$} & \multicolumn{6}{|c|}{ Faixa Etária (\%) } \\
\hline & \multicolumn{2}{|c|}{ Até 12 anos } & \multicolumn{2}{|c|}{ 13-45 anos } & \multicolumn{2}{|c|}{ + de 45 anos } & \multicolumn{2}{|c|}{ Até 12 anos } & \multicolumn{2}{|c|}{$13-45$ anos } & \multicolumn{2}{|c|}{ + de 45 anos } \\
\hline & MAS & FEM & MAS & FEM & MAS & FEM & MAS & FEM & MAS & FEM & MAS & FEM \\
\hline $1850-1854$ & 56 & 71 & 86 & 91 & 29 & 17 & 16,00 & 20,28 & 24,57 & 26,00 & 8,29 & 4,86 \\
\hline 1855-1859 & 120 & 104 & 147 & 161 & 50 & 60 & 18,69 & 16,20 & 22,90 & 25,08 & 7,78 & 9,35 \\
\hline 1860-1864 & 84 & 120 & 118 & 127 & 32 & 41 & 16,09 & 22,99 & 22,60 & 24,34 & 6,13 & 7,85 \\
\hline $1865-1870$ & 153 & 111 & 175 & 217 & 48 & 45 & 20,43 & 14,82 & 23,36 & 28,97 & 6,41 & 6,01 \\
\hline
\end{tabular}

Grão-Pará como forma de aplicabilidade do projeto da classe abastada da Província que pretendiam alinhar o Grão-Pará aos costumes e hábitos europeus. Por essa forma, reconheceram no modelo normalista de formação de professores o meio pelo qual poderiam doutrinar os agentes propagadores desses ideais no interior da Província, que estivessem afinados com suas políticas e ideias de modernização.

No entanto, depreendemos que não fora uma tarefa fácil e tão pouco fora uma unanimidade entre a classe política da Província, pois houve grande resistência dos políticos liberais a este projeto do Governo em formar um "exército" de professores que comungassem de sua ideologia política. Além, do desejo de alguns políticos e intelectuais liberais em adotar o modelo estadunidense de ensino para o Grão-Pará e para o Império do Brasil.

Não poderíamos encerrar este debate, sem destacarmos uma importante questão, isto é, a falta de medidas e discussões relacionadas à inserção dos negros da Província no sistema de Instrução Pública, pois eram numericamente significativos na sociedade paraense da época, mas os dirigentes e deputados provinciais ignoraram essa presença em seus debates e ações relacionados ao sistema de Instrução Pública, uma vez que em nenhum momento de seus Discursos, Relatórios, Ofícios e Falas direcionadas à Assembleia Legislativa Provincial, dedicaram atenção a essa questão.

Para melhor ressaltarmos a presença quantitativa de negros escravos no período, elaboramos o quadro 1, abaixo descrito, com base em inventários post-mortem do Arquivo Público do Pará.

No caso específico da capital da Província, cidade de Belém, conforme o quadro acima, o número de negros escravizados, no período de 1850 a 1870 , eram de 2.263 , entre crianças, jovens e adultos que foram fadados ao analfabetismo das matrizes educacionais brasileiras, haja vista que, como reafirmamos, em nenhum momento dos Discursos, Falas, Relatórios e Ofícios da Presidência da Província houve alguma discussão relacionada à necessidade de se instruir o negro liberto ou escravizado.

Este fato nos leva a depreender que o projeto de instrução e de formação de professores do Grão-Pará esteve centrado na necessidade de civilizar e formar o cidadão, com claros objetivos de possibilitar a adesão deste cidadão ao projeto de sociedade da classe abastada da Província, que seguindo a lógica econômica internacional, necessitava de trabalhadores operosos e aptos a desenvolver as atividades industriais em voga na Província. Não havendo, por conseguinte, a necessidade premente de instruir os negros, pois havia também o receio de que por meio do processo de instrução, estes se organizassem e promovessem um levante contra o Estado e a ordem social estabelecida.

Por fim, comungamos com Xavier (1992) e França (1997), quando evidenciam que os reais objetivos do Império era a promoção de uma educação de elite para a elite, restando ao povo apenas uma instrução incipiente para se garantir e propagar os ideais de educação e sociedade que se queria para o Brasil, assim como para o Grão-Pará, o que acaba por contrastar com seus próprios discursos, que baseados nos pressupostos iluministas, primavam por uma instrução que promovesse a conscientização dos direitos e 
deveres do cidadão, onde estes pudessem estar aptos a corroborar com a sociedade por meio de proposições legais que viessem a melhorar a sociedade como um todo.

Trata-se do contraste entre o discurso e a prática, pois por meio do discurso os dirigentes e políticos do Império e os da Província do Grão-Pará tentavam mascarar seus reais objetivos, demonstrando que a própria constituição discursiva desta classe dirigente estava a serviço desta empreitada conservadora da ordem social vigente.

Deste modo, procuramos demonstrar que o Grão-Pará não esteve alheio a essas questões, pois logo após a criação da primeira Escola Normal do Brasil, na cidade de Niterói, Província do Rio de Janeiro, já se repercutiu na Província do Pará a necessidade de criação de uma instituição destinada ao preparo específico de professores à luz do modelo normalista, isto é, o projeto nacional de criação e consolidação das Escolas Normais foi alvo de aspirações políticas em Belém ainda na primeira metade do século XIX, apesar de ter se consolidado apenas na década de 1870, o que acreditamos ter sido em função de uma ambiência política e social distinta, porque entre os anos de 1835 e 1840 ocorreu o processo revolucionário cabano, ${ }^{12}$ causando uma instabilidade política e administrativa na Província, e a própria legislatura provincial se inicia apenas em 1838.

Em síntese, não havia inicialmente uma ambiência política, econômica e social que propiciasse a consolidação da Escola Normal do Pará, instituida legalmente no ano de 1839, o que só foi alcançado em 1871, devido à próspera economia paraense, que ano após ano aumentatava sua arrecadação alfandegária, muito em função da crescente economia gomífera, da introdução da navegação a vapor na região e da abertura à navegação internacional do Rio Amazonas, que garantiram uma ambiência social e os recursos necessários para a instalação desta instituição na capital da Província, cidade de Belém, o que Monarcha (1999) também identifcou na Província de São Paulo, que só instituiu sua Escola Normal a partir, do que ele demominou, de um "surto de desenvolvimento".

\section{Referências}

ARAÚJO, José Carlos Souza. A Gênese da Escola Normal de Uberlândia, MG: o contexto estadual e a independência cultural em 1926. In: ARAÚJO, José Carlos Souza; FREITAS, Ana Maria Gonçalves Bueno de; LOPES, Antônio de Pádua Carvalho (orgs.). As Escolas Normais no Brasil: do Império à República. Campinas, SP: Editora Alínea, 2008.

ARAÚJO, José Carlos Souza; FREITAS, Ana Maria Gonçalves Bueno de; LOPES, Antônio de Pádua Carvalho (orgs.). As Escolas Normais no Brasil: do Império à República. Campinas, SP: Editora Alínea, 2008.

BOTO, Carlota. Na Revolução Francesa, os princípios democráticos da escola pública, laica e gratuita: o relatório de Condorcet. Revista Educação e Sociedade. vol. 24, no.84, Campinas, Set. 2003. pp. 735-762.

BRITO, Elias Santos de. Educazione e instruzione della scuola normale: celebrações e durezas das professoras e professores da Escola Normal na aurora da República paraense (1890-1908). 2005. Monografia de Graduação - Faculdade de História. Universidade Federal do Pará, Belém.

BURKE, Peter. História e teoria social. São Paulo: UNESP, 2002.

COUTEL, C. À l'école de Condorcet. Contre l'orléanisme des esprits. Paris: ellipses/éditions marketing S.A., 1996. 
FRANÇA, Maria do Perpétuo Socorro de Souza Avelino de. Raízes históricas do ensino secundário público na Província do Grão Pará: o Liceu Paraense. 1997. Dissertação (Mestrado) - Faculdade de Educação. Universidade Estadual de Campinas, Campinas.

GONDRA, J. G.; SCHUELER, A. Educação, poder e sociedade no Império Brasileiro. São Paulo: Editora Cortez, 2008.

GREGÓRIO, Vitor Marcos. Uma face de Jano: a navegação do rio Amazonas e a formação do Estado brasileiro (1838-1867). 2008. Dissertação (Mestrado em História Social) - Faculdade de Filosofia, Letras e Ciências Humanas, Universidade de São Paulo, São Paulo.

KINTZLER, K. C. Condorcet, l'instruction publique et la naissance du citoyen. Paris: Folio - Essais, Minerve, 1994.

LE GOFF, Jacques. História e Memória. Tradução Bernardo Leitão [et al.]. $5^{a}$ ed. Campinas, SP: Editora UNICAMP, 2003.

MALHEIROS, Rogério Guimarães. Formação de Professores na Província do GrãoPará: os discursos de seus administradores acerca da necessidade de se instaurar uma Escola Normal (1838 - 1871). 2012. 253f. Dissertação (Mestrado) - Programa de PósGraduação em Educação. Universidade Federal do Pará, Belém.

MALHEIROS, R. G.; ROCHA, G. O. R. da. Instrução, Ciência e Civilização: a Província do Grão-Pará e as influências francesa e estadunidense nas questões educacionais (1860 - 1870). Revista HISTEDBR On-line, Campinas, n.48, p. 77-92 Dez.2012 - ISSN: 1676-2584.

MONARCHA, Carlos. A Escola Normal da Praça - o lado noturno das luzes. São Paulo: Editora da Unicamp, 1999.

NUNES, Clarice (Org.). O Passado sempre presente. São Paulo: Cortez, 1992.

PARÁ, Governo da Província do. Relatório ao Exm. Senr. Dr. Francisco Maria Corrêa de Sá e Benevides, pelo Exm. Senr. Dr. Pedro Vicente de Azevedo, por ocasião de passar-lhe a administração da Província do Pará, no dia 17 de janeiro de 1875. Pará: Typographia do Diario do Gram-Pará, 1875. Disponível em: www.crl.edu/areastudies/LAMP/index.htm. Acesso em: 12 mar. 2012.

PARÁ, Governo da Província do. Relatorio apresentado à Assembléa Legislativa Provincial na segunda sessão da $17^{\text {a }}$ Legislatura, pelo Dr. Abel Graça Presidente da Provincia. Pará: Typographia do Diario do Gram-Pará, 1871. Disponível em: www.crl.edu/areastudies/LAMP/index.htm. Acesso em: 12 mar. 2012.

PARÁ, Governo da Província do. Relatório apresentado a Assembleia Legislativa Provincial, na primeira sessão da $19^{a}$ legislatura pelo Presidente da Província do Pará, o Excelentíssimo Senhor Doutor Pedro Vicente de Azevedo, em 15 de fevereiro de 1874b. Pará: Typographia do Diario do Gram-Pará, 1874. Disponível em: www.crl.edu/areastudies/LAMP/index.htm. Acesso em: 12 mar. 2012.

PARÁ, Governo da Província do. Relatório apresentado pelo Presidente do Gram-Pará, Leitão da cunha, em 8 de dezembro de 1858. Disponível em: www.crl.edu/areastudies/LAMP/index.htm. Acesso em: 12 mar. 2012. 
PARÁ, Governo da Província do. Relatório dos Negócios da Província do Pará eleabora do pelo Secretário Geral da Província Domingos Soares Ferreira Penna, e apresentado pelo Presidente Couto de Magalhães à Assembléia Legislativa Provincial, em 15 de agosto de 1864. Pará: Typographia de Frederico Carlos Rhossard, 1864. Disponível em: www.crl.edu/areastudies/LAMP/index.htm. Acesso em: 12 mar. 2012.

PARÁ, Governo da Província do. Discurso recitado pelo Exc ${ }^{\circ}$. Snr. Doutor Bernardo de Souza Franco, Presidente da Província do Pará, quando abrio a Assembleia Legislativa Provincial, no dia 15 de agosto de 1839. Pará: Typographia Restaurada de Santos \& menor, 1839. Disponível em: www.crl.edu/areastudies/LAMP/index.htm. Acesso em: 12 mar. 2012.

PARÁ, Governo da Província do. Falla que o Exmº Snr. Conselheiro desta Provincia dirigiu à Assemblea Legislativa Provincial na abertura da mesma Assemblea no dia 15 de Agosto de 1854. Pará: Typographia da Aurora Paraense, 1854. Disponível em: www.crl.edu/areastudies/LAMP/index.htm. Acesso em: 12 mar. 2012.

RICCI, Magda. O fim do Grão-Pará e o nascimento do Brasil: Movimentos Sociais, Levantes e Deserções no Alvorecer do Novo Império (1808-1840). In: PRIORE, Mary Del\& GOMES, Flávio dos Santos (orgs.). Os senhores dos rios. Amazônia, margens e histórias. Rio de Janeiro: Elsevier, 2003.

SILVA, Sidney Reinaldo. Direitos humanos e instrução pública segundo Condorcet. Educação em Revista, Marília, v. 11, n.12, p. 1-18, Jan.-Jun. 2010.

VILLELA, H. de O. S. A primeira escola normal do Brasil. In: NUNES, Clarice (Org.). O Passado sempre presente. São Paulo: Cortez, 1992.

XAVIER, Maria Elizabete S. Prado. Poder político e educação de elite. 3.ed., São Paulo: Cortez: Autores Associados, 1992.

\section{Notas}

\footnotetext{
${ }^{1}$ Mestre em Educação pela UFPA rogeriomalheiros@yahoo.com.br

2 Doutorando em Educação pela UFPA jonhpb@yahoo.com.br

${ }^{3}$ O Liceu Paraense, instituição de ensino criada na década de 1840, dedicava-se ao ensino de jovens do sexo masculino, enquanto que o Colégio Nossa Senhora do Amparo, dedicava-se a instrução de jovens do sexo feminino.

${ }^{4}$ Segundo o historiador Jacques Le Goff (2003), a modernidade, a partir da segunda metade do século XIX, apresenta-se como um conceito intimamente relacionado à estética, a mentalidade e aos costumes de uma dada sociedade e que os termos "modernismo", "modernização" e "modernidade" são uma herança histórica da querela acerca da dualidade antigo/moderno.

${ }^{5}$ No caso específico da Província do Grão-Pará, temos, neste mesmo período, certa influência do modelo educacional dos Estados Unidos da América, que já se figurava entre alguns políticos e intelectuais da Província, como uma alternativa viável para solucionar os problemas do sistema de Instrução Pública do Pará. Entre estes políticos e intelectuais podemos citar o naturalista e etnólogo, Domingos Soares Ferreira Penna, que defendia o modelo estadunidense como o que poderia sanar os graves problemas relacionados à Instrução Pública da Província do Pará e do Império do Brasil. Acerca desta questão, Cf.: MALHEIROS, R. G.; ROCHA, G. O. R. da. Instrução, Ciência e Civilização: a Província do Grão-Pará e as influências francesa e estadunidense nas questões educacionais (1860 - 1870). Revista HISTEDBR On-line, Campinas, n.48, p. 77-92 Dez.2012 - ISSN: 1676-2584.
} 
${ }^{6}$ compreendemos o termo "modelo" na perspectiva de Burke (2002, p. 47) quando evidencia que o mesmo se trata de uma "[...] construção intelectual simplificadora da realidade, para salientar o recorrente, o geral e o típico, apresentados na forma de conjuntos de características ou atributos [...]”. E para o percebimento de suas funcionalidades, o autor ressalta que "[...] sua utilidade depende da completa omissão de alguns elementos limitados ou 'variáveis' em um coerente sistema interno de partes interdependentes [...]”, o que garante a eficiencia discursiva do modelo, neste caso, o modelo normalista francês de ensino e de formação de professores (Cf. MALHEIROS, 2012).

${ }^{7}$ O Liberal do Pará. Belém, 17 de novembro de 1889, p. 1.

8 Acerca desta questão da heterogeneidade de sujeitos, formas, espaços e práticas educativas formais e informais que coexistiram no contexto do período imperial brasileiro Cf.: GONDRA, J. G.; SCHUELER, A. Educação, poder e sociedade no Império Brasileiro. São Paulo: Editora Cortez, 2008.

${ }^{9}$ A Escola Normal da Província do Rio de Janeiro foi criada em 1835, temos informação ainda que em Minas Gerais fora criada em 1835 (instalada em 1840), na Bahia em 1836 (instalada em 1841), Mato Grosso em 1837 e São Paulo em 1846.

${ }^{10}$ Pelo Padroado, o Governo Imperial poderia intervir em assuntos eclesiásticos, podia apresentar candidatos a ocuparem cargos na Igreja como o de Bispo, tinha o direito de aceitar recursos contra as decisões dos Bispos, de cobrar o dízimo dos fiéis católicos e a obrigação de pagar um salário aos Bispos e párocos, além de viabilizar a proteção das Ordens religiosas. O Padroado dava também poderes ao Governo de intervir e estabelecer sansões contra os religiosos que não aceitassem suas determinações. O exemplo mais comum é a "questão religiosa" ocorrida na segunda metade do século XIX, onde os bispos do Pará, Dom Macedo Costa, e de Olinda, Dom Vital, foram presos pelo Governo Imperial por não terem obedecido às ordens do Imperador. Os dois religiosos, assim como Dom Romualdo de Seixas, eram adeptos dos ideais de romanização, desejavam maior autonomia para a Igreja e que se estreitassem suas relações com Roma (Cf. MALHEIROS, R. G. Igreja e Estado: discursos, tensões e acordos políticos (1883 - 1891). Belém: Universidade Federal do Pará - Monografia de Graduação, 2008; . Tensões e negociações entre Igreja e Estado: arrazoamentos e acordos políticos e um período de aceleradas transformações. MNEME REVISTA DE HUMANIDADES, 11(29), 2011 - JAN / JULHO Publicação do Departamento de História da Universidade Federal do Rio Grande do Norte - Centro de Ensino Superior do Seridó - Campus de Caicó. Semestral ISSN - 1518-3394. Disponível em http://www.periodicos.ufrn.br/ojs/index.php/mneme).

${ }^{11}$ A Escola Normal do Pará é reaberta pelo Presidente Pedro Vicente de Azevedo, por meio do Regulamento 9, de junho de 1874, que reabriu a Escola Normal com diretoria desmembrada do Liceu Paraense (Cf. PARÁ, 1875 , p. 21).

${ }^{12}$ O período de 1835 a 1840 é ratificado pela historiografia nacional e regional como o início e o final do movimento revolucionário cabano. A Capital da Província do Pará, cidade de Belém, fora tomada em 1835, e posteriormente, com a nomeação do General d'Andréa em 1836, como novo Presidente da Província, o movimento fora reprimido na cidade e permaneceu no interior da Província, sendo os seus últimos focos extintos apenas no ano 1840. Para melhor compreensão do tema, Cf. RICCI, Magda. O fim do Grão-Pará e o nascimento do Brasil: Movimentos Sociais, Levantes e Deserções no Alvorecer do Novo Império (18081840). In: PRIORE, Mary Del\& GOMES, Flávio dos Santos (orgs.). Os senhores dos rios. Amazônia, margens e histórias. Rio de Janeiro: Elsevier, 2003.

Recebido: $\quad$ março/13 Aprovado: outubro/13 